\title{
Improving Students and Community Participation in Preserving Mangrove Forest Bangkala Jeneponto South Sulawesi with a Constructivism based Booklet
}

\author{
Astuti Muh. Amin \\ Graduate Student of Biology Education Universitas Negeri Malang \\ Universitas Pejuang Republik Indonesia \\ email: astutiamin@gmail.com.
}

\begin{abstract}
Knowledge dominantly affects community attitudes and participation in mangrove forest conservation. One of the effective ways to solve issues related to preserving mangrove forest in Jeneponto regency is to distribute a constructivism based booklet which introduces the functions, impacts, and management of the forest. This study was conducted in Bangkala District, Jeneponto regency, South Sulawesi from 11 August 2016 to 25 December 2016. Purposive sampling was employed to determine the research sample based on certain consideration. Data was collected using: (1) a questionnaire to elicit responses from some students and community members in Bangkala Jeneponto South Sulawesi towards a booklet developed on the constructivist theory; (2) another questionnaire and interview schedule to obtain community perception on the forest conservation activities; (3) socialization activities at schools and community centers related to the importance of sustainable mangrove forest development. Research findings indicate that: (1) the students and the community members of Bangkala, Jeneponto, South Sulawesi have provided positive and supportive responses towards the development of the constructivism booklet; (2) the society members have realized the significance of mangrove forest development; (3) overall, the students and the community members in Bangkala, Jeneponto, South Sulawesi have been highly involved in preserving the mangrove forest. Assistance to sustain this participation; however, is still necessary.
\end{abstract}

Keywords: Booklet, Mangrove Conservation, Students, Participation, Community.

\section{INTRODUCTION}

Many mangrove forests have been intentionally converted for aquaculture, agriculture, and settlement areas. This conversion exists due to weak law enforcement and low society awareness of the coastal environment. According to a report written by Pramudji (2001; 2002; 2003), that condition can be found in the coastal areas of East Borneo, Sumbawa, South Sulawesi, and along the north coast of Java island and East Java.

A study conducted by Hartati and Harudu (2016) shows that human activities are one of the factors that contribute to deforestation in Lowu-Lowu. Those activities include aquaculture and illegal logging. Humans cut down forest vegetation and collect it for firewood and building materials. In addition to that, the society members have limited knowledge of whether mangrove forest is still in good condition or not. As a result, people are unaware of the existence of forest rehabilitation projects. Notoatmojo (1997) states that knowledge reflects community attitudes. Adequate knowledge accommodates rational behaviour and attitudes, especially towards mangrove forest management.

The mangrove forests conversion has also occurred in Bangkala, Jeneponto, South Sulawesi. The increasing demand for salt in the dry season is one of the reasons why the farmers in the area developed its aquaculture widely (Amin et al., 2016). This can also be a result of community lack of awareness of the mangrove forests importance to the environment (Bachtiar, 2014). Knowledge dominantly affects the community attitudes and participation in mangrove forests preservation (Sari, 1999; Syaban, 2007; Hardianti, 2014). The result of a research conducted on community

Bioedukasi Vol. XVI. No.1 April 2018

Received 8 Maret 2018 | Received in revised form 5 April 2018 | Accepted 15 April 2018| Published online 31 April 2018 
basic knowledge of mangrove forests in Bangkala, Jeneponto, South Sulawesi, in fact, indicates that $40,26 \%$ of the society members have very low awareness of mangrove forests, $37,66 \%$ have low awareness, $18,18 \%$ have enough knowledge, and only 3,90\% have high awareness of mangrove forests preservation (Amin et al., 2016). Therefore, it is necessary to promote the community awareness of the mangrove forests functions and conservation.

Mangrove forests serve both ecological and economic functions (Pardede, 2013), either to the local, regional, or global community. Thus, they need to be managed and preserved well. According to Alimuna, et al (2016), some strategies that can be applied in managing the mangrove forests include: 1) mapping of zones determination; 2) planning a mangrove forests conservation activity; 3 ) rehabilitating the forests by planting seeds together with the community and government; 4) forests patrolling; 5) improving the community welfare; and 6) sharing knowledge of the functions, benefits, and preservation of the mangrove forests with the society members.

According to Pramuji (2004), a feasible program to manage and rehabilitate mangrove is to develop human resources through training and schooling. Jeneponto regency has attempted to do the socialization of mangrove forests' functions, impact, and management with a constructivism based booklet. Booklet or brochure is a written material containing information related to an issue (Satmoko and Harini, 2006). The booklet provides information related to mangrove forests and techniques to rehabilitate the forests. It is designed to be attractive and understandable for students. The constructivists argue that to acquire knowledge someone needs to reconstruct his/her existing cognitive structure and adjust it with new information in order that new knowledge can be adapted. The distribution of the constructivism based booklet is expected to improve learners' awareness of the importance of the mangrove forests. Hopefully, future generation can recognize the characteristics of mangrove forests destruction and get involved in socializing the information with their family members and people around.

Based on the explanation above, research questions can be formulated into (1) How do learners and community in Bangkala, Jeneponto, South Sulawesi react towards the constructivism based booklet? (2) What is the community perception on the mangrove forests conservation? (3) How do learners and community participate in preserving mangrove forests in Bangkala, Jeneponto, South Sulawesi?

\section{RESEARCH METHOD}

This research was conducted in Bangkala, Jeneponto, South Sulawesi Selatan from August 11, 2016, to December 25, 2016. Respondents were selected using purposive sampling technique which determined research samples with a certain consideration. The number of the respondents was decided using a formula suggested by Slovin (Kusmayadi and Endar, 2000). Around 150 students who participated in this research came from Public Junior High School No.3 (SMP Negeri 3) and Public Senior High School No.7 (SMA Negeri 7) in Bangkala, Jeneponto. Meanwhile, the number of community members involved in this research was 75 people.

Data was collected using: (1) a questionnaire to elicit responses from some students and community members in Bangkala Jeneponto South Sulawesi towards a booklet developed on the constructivist theory; (2) another questionnaire and interview schedule to obtain community perception on the forest conservation activities; (3) socialization activities at schools and community centers related to the importance of sustainable mangrove forest development. The booklet used in this study had been validated by two environment experts. According to Umar 
(2005), the average scores of community perception on mangrove forests' destruction, management, and preservation cover strongly disagree $(1,00-1,8)$; disagree $(1,8-2,6)$; uncertain $(2,6-3,4)$; agree $(3,4-$ $4,2)$; strongly agree $(4,2-5,00)$.

\section{RESEARCH FINDINGS}

\section{Students and Community Responses Towards the Constructivism Based Booklet}

The following table describes SMP Negeri 3 students' responses towards the constructivism based booklet.

Table 1. Recapitulation of Data of SMP Negeri 3 students' responses towards the constructivism based booklet.

\begin{tabular}{|c|c|c|c|c|}
\hline $\begin{array}{c}\mathrm{N} \\
\mathrm{O}\end{array}$ & Question Items & Responses & Respondents & Percentages \\
\hline 1 & $\begin{array}{l}\text { How do you understand the } \\
\text { development of a booklet } \\
\text { with mangrove forests theme? }\end{array}$ & $\begin{array}{ll}\text { a. } & \text { Very good } \\
\text { b. } & \text { Quite good } \\
\text { c. } & \text { Not good enough } \\
\text { d. } & \text { Very bad }\end{array}$ & $\begin{array}{c}21 \\
35 \\
19 \\
0 \\
0\end{array}$ & $\begin{array}{c}28 \\
46,67 \\
25,33 \\
0 \\
0\end{array}$ \\
\hline 2 & $\begin{array}{l}\text { Are you interested in reading } \\
\text { a booklet on mangrove } \\
\text { forests theme? }\end{array}$ & $\begin{array}{ll}\text { a. } & \text { Very interested } \\
\text { b. } & \text { Quite interested } \\
\text { c. } & \text { Not really interested } \\
\text { d. } & \text { Not interested at all }\end{array}$ & $\begin{array}{c}38 \\
25 \\
12 \\
0 \\
0\end{array}$ & $\begin{array}{c}50,67 \\
33,33 \\
16 \\
0 \\
0\end{array}$ \\
\hline 3 & $\begin{array}{l}\text { How do you respond to the } \\
\text { development of a booklet } \\
\text { with mangrove forests theme? }\end{array}$ & $\begin{array}{l}\text { a. Supportive } \\
\text { b. Not supportive }\end{array}$ & $\begin{array}{c}74 \\
1\end{array}$ & $\begin{array}{c}98,67 \\
1,33\end{array}$ \\
\hline 4 & $\begin{array}{l}\text { Does the booklet present } \\
\text { materials and application of } \\
\text { concepts related to mangrove } \\
\text { forests conservation? }\end{array}$ & $\begin{array}{ll}\text { a. } & \text { Very good } \\
\text { b. } & \text { Good } \\
\text { c. } & \text { Quite Good } \\
\text { d. } & \text { Not good enough } \\
\text { e. } & \text { Very bad }\end{array}$ & $\begin{array}{c}29 \\
26 \\
20 \\
0 \\
0\end{array}$ & $\begin{array}{c}38,67 \\
34,67 \\
26,67 \\
0 \\
0\end{array}$ \\
\hline 5 & $\begin{array}{l}\text { Does the booklet provide } \\
\text { information about mangrove } \\
\text { forests conservation and } \\
\text { management? }\end{array}$ & $\begin{array}{l}\text { a. Yes } \\
\text { b. Not sure } \\
\text { c. No }\end{array}$ & $\begin{array}{l}72 \\
3 \\
0\end{array}$ & $\begin{array}{c}96 \\
4 \\
0\end{array}$ \\
\hline 6 & $\begin{array}{l}\text { Does the booklet improve } \\
\text { your motivation to preserve } \\
\text { and manage mangrove } \\
\text { forests? }\end{array}$ & $\begin{array}{ll}\text { a. Yes } \\
\text { b. Not sure } \\
\text { c. No }\end{array}$ & $\begin{array}{c}71 \\
4 \\
0\end{array}$ & $\begin{array}{c}94,67 \\
5,33 \\
0\end{array}$ \\
\hline
\end{tabular}

The following table presents SMA Negeri 7 students' responses towards the constructivism based booklet.

Table 2. Recapitulation of Data of SMA Negeri 7 students' responses towards the constructivism based booklet.

\begin{tabular}{|c|c|c|c|c|}
\hline No & Question Items & Responses & Respondents & Percentages \\
\hline \multirow[t]{5}{*}{1} & How do you understand the & a. $\quad$ Very good & 52 & 69,33 \\
\hline & development of a booklet & b. Good & 23 & 30,67 \\
\hline & with mangrove forests & c. Quite Good & 0 & 0 \\
\hline & theme? & d. Not good enough & 0 & 0 \\
\hline & & e. Very bad & 0 & 0 \\
\hline
\end{tabular}




\begin{tabular}{|c|c|c|c|c|}
\hline \multirow[t]{5}{*}{2} & \multirow{5}{*}{$\begin{array}{l}\text { Are you interested in } \\
\text { reading a booklet on } \\
\text { mangrove forests theme? }\end{array}$} & a. Very interested & 44 & 58,67 \\
\hline & & b. Interested & 31 & 41,33 \\
\hline & & c. Quite Interested & 0 & 0 \\
\hline & & d. Less Interested & 0 & 0 \\
\hline & & e. Not Interested & 0 & 0 \\
\hline \multirow[t]{2}{*}{3} & How do you respond to the & a. Supportive & 75 & 100 \\
\hline & $\begin{array}{l}\text { development of a booklet } \\
\text { with mangrove forests } \\
\text { theme? }\end{array}$ & b. Not Supportive & 0 & 0 \\
\hline \multirow[t]{5}{*}{4} & Does the booklet present & a. Very Good & 45 & 60 \\
\hline & materials and application of & b. Good & 25 & 33,33 \\
\hline & concepts related to & c. Quite Good & 5 & 6,67 \\
\hline & mangrove forests & d. Not good enough & 0 & 0 \\
\hline & conservation? & e. Very bad & 0 & 0 \\
\hline \multirow[t]{3}{*}{5} & Does the booklet provide & a. Yes & 73 & 97,33 \\
\hline & information about & b. Not sure & 2 & 2,67 \\
\hline & $\begin{array}{l}\text { mangrove forests } \\
\text { conservation and } \\
\text { management? }\end{array}$ & c. No & 0 & \\
\hline \multirow[t]{3}{*}{6} & Does the booklet improve & a. Yes & 75 & 100 \\
\hline & your motivation to preserve & b. Not Sure & 0 & 0 \\
\hline & $\begin{array}{l}\text { and manage mangrove } \\
\text { forests? }\end{array}$ & c. No & 0 & 0 \\
\hline
\end{tabular}

The following table shows responses provided by community members in Bangkala, Jeneponto towards the constructivism based booklet.

Table 3. Recapitulation of Data of Community responses towards the constructivism based booklet.

\begin{tabular}{|c|c|c|c|c|}
\hline $\begin{array}{l}\mathrm{N} \\
\mathrm{O}\end{array}$ & Question Items & Responses & Respondents & Percentages \\
\hline \multirow[t]{5}{*}{1} & \multirow{5}{*}{$\begin{array}{l}\text { How do you understand the } \\
\text { development of a booklet } \\
\text { with mangrove forests theme? }\end{array}$} & a. Very good & 27 & 36 \\
\hline & & b. Good & 39 & 52 \\
\hline & & c. Quite Good & 9 & 12 \\
\hline & & d. Not good enough & 0 & 0 \\
\hline & & e. Very bad & 0 & 0 \\
\hline \multirow[t]{5}{*}{2} & \multirow{5}{*}{$\begin{array}{l}\text { Are you interested in reading } \\
\text { a booklet on mangrove } \\
\text { forests theme? }\end{array}$} & a. Very interested & 21 & 28 \\
\hline & & b. Interested & 35 & 46,67 \\
\hline & & c. Quite Interested & 19 & 25,33 \\
\hline & & d. Less Interested & 0 & 0 \\
\hline & & e. Not Interested & 0 & 0 \\
\hline \multirow[t]{2}{*}{3} & \multirow{2}{*}{$\begin{array}{l}\text { How do you respond to the } \\
\text { development of a booklet } \\
\text { with mangrove forests theme? }\end{array}$} & a. Supportive & 75 & 100 \\
\hline & & b. Not Supportive & 0 & 0 \\
\hline \multirow[t]{4}{*}{4} & \multirow{4}{*}{$\begin{array}{l}\text { Does the booklet present } \\
\text { materials and application of } \\
\text { concepts related to mangrove } \\
\text { forests conservation? }\end{array}$} & a. Very Good & 55 & 73,33 \\
\hline & & b. Good & 20 & 26,67 \\
\hline & & c. Quite Good & 0 & 0 \\
\hline & & $\begin{array}{l}\text { d. Not good enough } \\
\text { e. Very bad }\end{array}$ & 0 & 0 \\
\hline \multirow[t]{3}{*}{5} & \multirow{3}{*}{$\begin{array}{l}\text { Does the booklet provide } \\
\text { information about mangrove } \\
\text { forests conservation and } \\
\text { management? }\end{array}$} & a. Yes & 65 & 86,67 \\
\hline & & b. Not sure & 10 & 13,33 \\
\hline & & c. No & 0 & 0 \\
\hline \multirow[t]{3}{*}{6} & \multirow{3}{*}{$\begin{array}{l}\text { Does the booklet improve } \\
\text { your motivation to preserve } \\
\text { and manage mangrove } \\
\text { forests? }\end{array}$} & a. Yes & 72 & 96 \\
\hline & & b. Not Sure & 3 & 4 \\
\hline & & c. No & 0 & 0 \\
\hline
\end{tabular}

Bioedukasi Vol. XVI. No.1 April 2018 
Based on the data recapitulation, it can be concluded that the students and the community provided positive responses and were supportive of the development of a constructivism based booklet.

\section{Community Perception on The Attempts to Preserve Mangrove Forests in Bangkala, Jeneponto South Sulawesi}

Following is the data recapitulation of community perception on the attempts of forests conservation in Bangkala, Jeneponto, South Sulawesi.

Table 4. Community Perception of the Damage, Management, and Conservation of Mangrove Forests in Bangkala, Jeneponto, South Sulawesi

\begin{tabular}{|c|c|c|c|}
\hline No & Community perception & Average Score & Note \\
\hline $\mathrm{P} 1$ & $\begin{array}{l}\text { Mangrove forests are damaged due to the increasing } \\
\text { number of salt pond land openings. }\end{array}$ & 4,55 & Strongly agree \\
\hline $\mathrm{P} 2$ & $\begin{array}{l}\text { Mangrove forests are damaged due to the increasing } \\
\text { number of fish farm pond openings. }\end{array}$ & 3,67 & Agree \\
\hline $\mathrm{P} 3$ & $\begin{array}{l}\text { Mangrove forests are damaged by the irresponsible } \\
\text { humans. }\end{array}$ & 4,63 & Strongly agree \\
\hline $\mathrm{P} 4$ & $\begin{array}{l}\text { Mangrove forests are damaged by the environment } \\
\text { forces (waves, wind). }\end{array}$ & 3,57 & Agree \\
\hline P5 & Mangrove forests damage results in beach abrasion. & 3,59 & Agree \\
\hline P6 & $\begin{array}{l}\text { Mangrove forests damage affects the community } \\
\text { welfare. }\end{array}$ & 4,15 & Agree \\
\hline P7 & Mangrove forests damage affects ecological aspects. & 4,45 & Strongly agree \\
\hline P8 & $\begin{array}{l}\text { Mangrove forests need to be preserved as mutual } \\
\text { wealth. }\end{array}$ & 4,45 & Strongly agree \\
\hline $\mathrm{P} 9$ & $\begin{array}{l}\text { Mangrove forests need to be managed well in order } \\
\text { to keep it preserved. }\end{array}$ & 4,80 & Strongly agree \\
\hline P10 & $\begin{array}{l}\text { It is necessary to do socialization related to the way } \\
\text { to preserve mangrove forests. }\end{array}$ & 4,68 & Strongly agree \\
\hline P11 & $\begin{array}{l}\text { It is necessary to establish a law related to mangrove } \\
\text { forests management and conservation. }\end{array}$ & 4,51 & Strongly agree \\
\hline $\mathrm{P} 12$ & $\begin{array}{l}\text { Violation of the law must be followed up by giving } \\
\text { sanctions or punishment. }\end{array}$ & 4,33 & Strongly agree \\
\hline P13 & $\begin{array}{l}\text { Local people need to be involved in mangrove forests } \\
\text { management. }\end{array}$ & 3,87 & Agree \\
\hline P11 & $\begin{array}{l}\text { The management and conservation of the mangrove } \\
\text { forests do not have to be aligned with local wisdom } \\
\text { (local culture/custom) }\end{array}$ & 3,03 & Not sure \\
\hline $\mathrm{P} 12$ & $\begin{array}{l}\text { The mangrove forests management will prevent local } \\
\text { people from utilizing the forests or resources found in } \\
\text { them. }\end{array}$ & 2,48 & Disagree \\
\hline P13 & $\begin{array}{l}\text { Only some particular people will get the benefits } \\
\text { from the mangrove forests management. }\end{array}$ & 2,52 & Disagree \\
\hline P14 & $\begin{array}{l}\text { The migrant community does not need to obey the } \\
\text { law related to mangrove forests management and } \\
\text { conservation. }\end{array}$ & 3,00 & Not sure \\
\hline P15 & $\begin{array}{l}\text { High school and university students' involvement } \\
\text { plays a significant role in sustaining mangrove } \\
\text { forests. }\end{array}$ & 4,07 & Agree \\
\hline
\end{tabular}

The results of the data recapitulation presented in the table indicate that people who live in the coastal area started to realize the importance of mangrove forests conservation.

Bioedukasi Vol. XVI. No.1 April 2018 


\section{Students and Community Participation in Preserving Mangrove Forests in Bangkala, Jeneponto South Sulawesi.}

The following table presents the recapitulation of data of SMP Negeri 3 students' participation in preserving mangrove forests in Bangkala, Jeneponto, South Sulawesi.

Table 5. Recapitulation of Data of SMP Negeri 3 students' participation in preserving mangrove forests in Bangkala, Jeneponto, South Sulawesi.

\begin{tabular}{ccccc}
\hline No & Interval & Categories & Frequency & $\%$ \\
\hline 1 & $<40$ & Very low & 0 & 0 \\
2 & $40-55$ & Low & 6 & 8 \\
3 & $56-75$ & Medium & 10 & 13,33 \\
4 & $76-100$ & High & 59 & 78,67 \\
\hline
\end{tabular}

According to table 5, it is found out that SMP Negeri 3 students' participation in preserving mangrove forests was 78,67\%. Meanwhile, the following table depicts the recapitulation of data of SMA Negeri 7 students' participation in preserving mangrove forests in Bangkala, Jeneponto, South Sulawesi.

Table 6. Recapitulation of Data of SMA Negeri 7 students' participation in preserving mangrove forests in Bangkala, Jeneponto, South Sulawesi.

\begin{tabular}{ccccc}
\hline No & Interval & Categories & Frequency & $\%$ \\
\hline 1 & $<40$ & Very low & 0 & 0 \\
2 & $40-55$ & Low & 4 & 5,33 \\
3 & $56-75$ & Medium & 15 & 20 \\
4 & $76-100$ & High & 56 & 74,67 \\
\hline
\end{tabular}

According to table 6, it is found out that SMA Negeri 7 students' participation in preserving mangrove forests was $74,67 \%$. The table below shows the recapitulation of data of community participation in preserving mangrove forests in Bangkala, Jeneponto, South Sulawesi.

Table 7. Recapitulation of data on community participation in preserving mangrove forests

\begin{tabular}{ccccc}
\hline No & Interval & Categories & Frequency & $\%$ \\
\hline 1 & $<40$ & Very low & 0 & 0 \\
2 & $40-55$ & Low & 2 & 2,67 \\
3 & $56-75$ & Medium & 6 & 8 \\
4 & $76-100$ & High & 67 & 89,33 \\
\hline
\end{tabular}

Table 7 indicates that community participation in preserving mangrove forests was $89,33 \%$. In conclusion, students and community participation in mangrove forests conservation were in high category.

\section{DISCUSSION}

The results of data analysis indicate that the students and community who live in the coastal area were really supportive of the development of a constructivism based booklet. Information related to the mangrove forests management and conservation was badly needed by the people who found some difficulties in accessing information on the internet. Positive responses towards the development of the booklet encouraged them to improve the efforts in preserving the mangrove forests. Previous related research reported that community effort in preserving mangrove ecosystem was very low (15,58\%); low (9,09\%); adequate (49,35\%); and high (25,97\%) (Amin et al., 2016). In addition to that, high school and university students' involvement in a socialization project also plays a crucial role in sustaining the mangrove forests. The coastal community was open to the enthusiasm brought by the young 
generation engaged in actions to preserve the environment as a mutual potential asset.

Assistance in mangrove forests management is important. It provides help for the community to get the answers to issues related to factors and concrete examples of mangrove forests devastation (Amal and Baharuddin, 2016). The persuasive approach also needs to involve local stakeholders and students. Hopefully, this activity can be continuously and regularly conducted. Wibowo (2013) explains that forests conservation needs both government and community active participation. Community awareness is crucial in this case because they who live nearby directly connect to the existence of the forests.

According to Pramudji (2004), there are some aspects that have not functioned effectively and need serious attention from all parties. They include (1) government policy; (2) socialization of the roles, benefits, and importance of mangrove forests for living creatures, including human beings; (3) socialization, rehabilitation, and conservation of mangrove forests; (4) law enforcement. Tree logging has become a serious threat to the existence of mangrove forests. It does not only result in deforestation but also change microclimate which also adversely affects the ecosystem in the area (Setyawan and Winarno, 2006). The results of the interview conducted with some local people indicate that government needs to take an action to prevent the mangrove forests from destruction. Violation of the law related to the forests conservation and management needs to be strictly followed up by giving sanctions or punishment. This is expected to give a deterrent effect on the irresponsible people.

The scarcity of the forests and the active participation of the coastal community contribute to the preservation of mangrove forests which support the availability of marine resources (Cie et al., 2010). The perception of the society members needs to be directed into positive so that they are willing to maintain and preserve mangrove forests. Dahuri (1996) states that the uncontrolled economical activities and community lack of awareness are the causes of mangrove forests destruction. All human activities which are related to the use of mangrove forests area in a great scale are also associated with high population and low economic level of the locals (Pramudji, 2000; Supriharyono, 2006). Kaunang (1999) shows that knowledge, attitudes, motivation, and active participation of the community are correlated. In other words, people who have better knowledge, attitudes, and motivation to preserve mangrove forests will perform more active participation. Therefore, they need coaching and assistance so that they can maintain their enthusiasm in preserving the mangrove forests.

\section{CONCLUSIONS AND SUGGESTION}

Based on the results of the present research, it can be concluded that:(1) the students and community members who live in Bangkala, Jeneponto, South Sulawesi have provided positive responses and been supportive of the development of the constructivism based booklet; (2) community perception was good and they started to recognize the importance of the mangrove forests conservation and management; (3) the participation of the students and the community in Bangkala, Jeneponto, South Sulawesi was high. Even so, it is still necessary to give coaching and provide assistance for the people continuously. The findings also suggest that the government should intensively improve the community awareness of mangrove forests conservation and management in a more persuasive way.

\section{REFERENCES}

Alimuna, W., Sunarto., Murti, S.H. 2016. Pengaruh Aktivitas Masyarakat terhadap Kerusakan Hutan Mangrove di Rarowatu Utara, Bombana Sulawesi Tenggara. https://jurnal.ugm.ac.id/mgi/article/ 
viewFile/13332/9549. Diakses pada tanggal 8 Agustus 2017.

Amal dan Baharuddin, I.I. 2016. Persepsi dan Partisipasi Masyarakat dalam Pengelolaan Hutan Mangrove Berbasis Masyarakat di Kecamatan Suppa Kabupaten Pinrang. \urnal Scientific Pinisi, 2 (1): 1-7.

Amin, M.A., Irawati, M.H., Rohman, F., Syamsuri, I. 2016. Sosialiasi Pengelolaan Hutan Mangrove Berkelanjutan sebagai Upaya Peningkatan Kesadaran Siswa dan masyarakat akan Dampak Alih Fungsi Lahan Mangrove (Studi Kasus di Kecamatan Bangkala Kabupaten Jeneponto Sulawesi Selatan). Prosiding Semiar Nasional Biologi FMIPA UNESA 20 Februari 2016, 330-338.

Bachtiar S. 2014. Pengetahuan dan Pendidikan kepada Masyarakat tentang Hutan Mangrove. Jurnal Pendidikan Biologi, 2 (2).

Cie, Y., Wisudo, S.H., Purbayanto, A., 2010. Partisipasi Masyarakat Nelayan dalam Pemanfaatan Kawasan Mangrove untuk Perikanan Tangkap di Halmahera Utara. http://www. repository.ipb.ac.id. Diakses pada tanggal 8 Agustus 2017.

Dahuri, R., Rais, J.S.P., Ginting., Sitepu. 1996. Pengelolaan Sumberdaya Wilayah Pesisir Secara Terpadu. Jakarta: Pradya Paramita.

Hardianti S, Eka P, Paskal S. 2014. Hubungan Pengetahuan Konservasi dengan Persepsi Nelayan tentang Kegiatan Penanaman Mangrove di Kampung Garapan Desa Tanjung Pasir Tangerang. Biosfer, 6 (2): 1014.
Hartati dan Harudu, L. 2016. Identifikasi Jenis-Jenis Kerusakan Ekosistem Hutan Mangrove Akibat Aktivitas Manusia di Kelurahan Lowu-Lowu Kecamatan Lea-Lea Kota Baubau. Jurnal Penelitian Pendidikan Geografi, 1 (1): 30-45.

Kaunang, E. 1999. Studi Tentang Pengetahuan Ekosistem, Motivasi, dan Sikap Terhadap Pelestarian Hutan Mangrove di Sulut. Tesis tidak dipublikasikan. Malang: IKIP Malang.

Kusumaningrum, $\mathrm{R}$ dan Endah, N, R. 2010.Sistem Pendukung Keputusan untuk Menganalisa Kesesuaian Jenis Vegetasi Mangrove Menggunakan Analytic Hierarchy Process (AHP). Semarang: Prosiding Seminar Nasional Ilmu Komputer Universitas Diponegoro.

Nanlohy, H., Bambang, A.N., Ambaryanto, Hutabarat, S. Analisis Persepsi Masyarakat terhadap Pengelolaan Kawasan Mangrove Teluk Kotania. Jurnal Wilayah dan Lingkungan, 2 (1): 89-98.

Notoatmodjo S. 1997. Ilmu Kesehatan Masyarakat. Jakarta: Rineka Cipta.

Pardede, E. 2013. Mangrove untuk Mendukung Lingkungan Hidup, Keanekaragaman Hayati dan Ketahanan Pangan. Dipresentasikan di Seminar Nasional Peranan Pers pada Pembangunan Pertanian Berwawasan Lingkungan Mendukung Kedaulatan Pangan Berkelanjutan, 21 Februari 2013.

Pramudji. 2001. Hutan Mangrove di Pantai Teluk Saleh, Sumbawa, Nusa Tenggara Barat (NTB). Dalam: Pesisir dan Pantai Indonesia (Atmadja W. S., Ruyitno, B.S. 
Sudibyo, I. Supangat, H.P.Hutagalong, A.S. Genisa, Sunarto Eds.) Pusat Penelitian dan Pengembangan Oseanologi LIPI, Jakarta. 49-58.

Pramudji. 2002. Kajian Hutan Mangrove di Kawasan Pesisir Kabupaten Penajam, Kalimantan Timur. Laporan penelitian, Pusat Penelitian Oseanogafi LIPI, Jakarta.

Pramudji. 2003. Keanekaragaman Flora di Hutan Mangrove Kawasan Pesisir Teluk Mandar, Polewali, Propinsi Sulawesi Selatan: Kajian Pendahuluan. Biota, 8 (3): 135-142.

Pramudji. 2004. Penanganan Hutan Mangrove di Kawasan Pesisir Indonesia: Suatu Program yang Sangat Mendesak. Oseana, 29 (1): 19-26.

Sari, S A. 1999. Pengetahuan, Sikap, dan Partisipasi Masyarakat dalam Pembuatan Sumur Resapan Air Hujan. Jurnal Teknologi, 12 (1): 5375.

Satmoko, S dan Harini T.A. 2006. Pengaruh bahasa booklet pada peningkatan pengetahuan peternak sapi perah tentang inseminasi buatan di kelurahan Nongkosawit, Kecamatan Gunungpati Kota
Semarang. Jurnal Penyuluhan 2(2): 78-82.

Setyawan, A.D., Winarno, K. 2006. Pemanfaatan Langsung Ekosistem Mangrove di Jawa Tengah dan Penggunaan Lahan di Sekitarnya; Kerusakan dan Upaya Distorasinya. Biodiversitas, 7 (3): 282-291.

Supriharyono. 2006. Konservasi Ekosistem Sumberdaya Hayati di Wilayah Pesisir dan Laut Tropis. Jakarta: PT.Gramedia Pustaka Utama.

Syaban R A. 2007. Kajian tentang Keterkaitan Latar Belakang Pendidikan, Pengetahuan Ekosistem Mangrove, Status Ekonomi Keluarga, Sikap dan Perilaku Nelayan dengan Upaya Pelestarian Hutan Mangrove di Kabupaten Pasuruan. Disertasi tidak diterbitkan. Malang: Universitas Negeri Malang.

Umar, H. 2005. Riset Sumber Daya Manusia dalam Organisasi. Jakarta: PT Gramedia Pustaka Utama.

Wibowo. 2009. Motivasi Dan Partisipasi Masyarakat Desa Buluh Cina Dalam Upaya Melestarikan Hutan Adat Buluh Cina Kec Siak Hulu Kab. Kampar Provinsi Riau. Jurnal Lingkungan Hidup. Vol.1. 